\title{
Three territory sign in cancer-related acute ischemic stroke
}

\section{Sinal de três territórios arteriais em acidente vascular cerebral isquêmico agudo relacionado a câncer}

Marcelo Houat DE BRITO ${ }^{1,2,3}$, Gabriela Almeida PIMENTEL ${ }^{1,2}$, Marcos Fernando de Lima DOCEMA', Mateus Correa da TRINDADE'1

A 64-year-old man, on regular use of apixaban due to atrial fibrillation (AF), was admitted to the hospital with sudden right upper limb weakness. Brain MRI (Figure 1) demonstrated a Three Territory Sign (TTS, bilateral anterior and posterior circulation acute ischemic diffusionweighted imaging lesions). Complimentary etiologic investigation diagnosed an adenocarcinoma of the ascending colon by full-body 18F-FDG PET/CT (Figure 2), followed by a local biopsy.

TTS is a highly specific marker and six times more frequently observed in malignancy-related than AF-related ischemic stroke ${ }^{1}$. The prothrombotic state of malignancy occurs due to the ability of tumor cells to activate the coagulation system ${ }^{2}$.

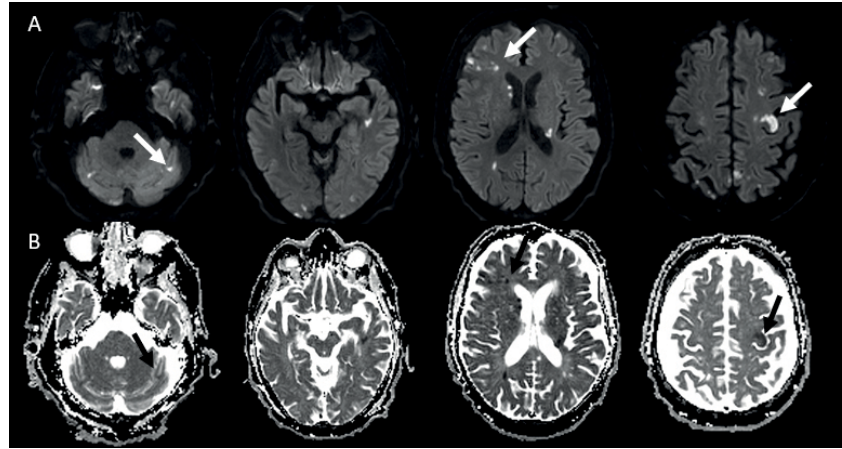

Figure 1. Brain MRI diffusion-weighted image - DWI (Row A) showing multiple high signal intensity lesions in the cerebral and cerebellar hemispheres involving three different vascular territories (Three Territory Sign), with apparent diffusion coefficient - ADC (Row B), showing the same lesions with low signal intensity.
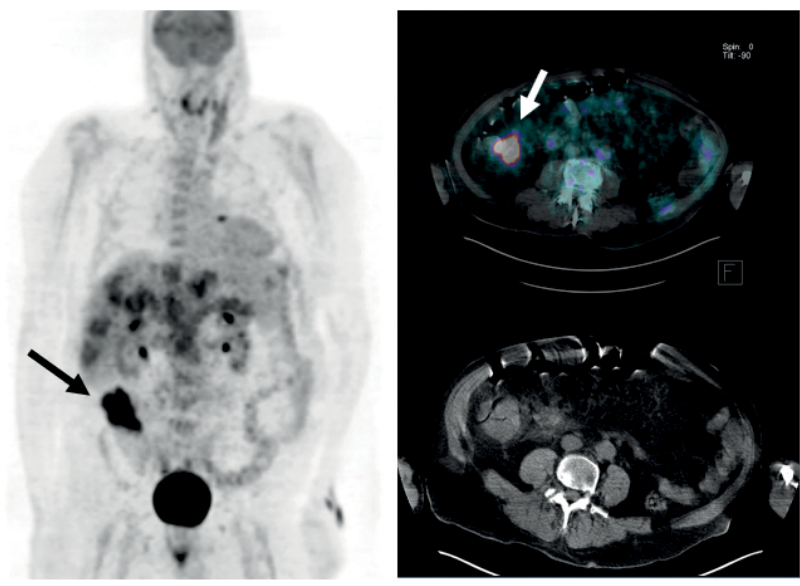

Figure 2. FDG-PET/CT showing hypermetabolic alterations compatible with cecum/ascending colon tumor (arrows) extending to adjacent adipose planes.

\section{References}

1. Nouh AM, Staff I, Finelli PF. Three Territory Sign: An MRI marker of malignancy-related ischemic stroke (Trousseau syndrome). Neurol Clin Pract. 2019 Apr;9(2):124-8. https://doi.org/10.1212/ CPJ.0000000000000603
2. Caine GJ, Stonelake PS, Lip GY, Kehoe ST. The hypercoagulable state of malignancy: pathogenesis and current debate. Neoplasia. 2002 Nov-Dec;4(6):465-73. https://doi.org/10.1038/ sj.neo.7900263

\footnotetext{
${ }^{1}$ Hospital Sírio-Libanês, São Paulo SP, Brazil.

${ }^{2}$ Universidade de São Paulo, Faculdade de Medicina, Hospital das Clínicas, Departamento de Neurologia, São Paulo SP, Brazil. ${ }^{3}$ Instituto do Câncer do Estado de São Paulo, São Paulo SP, Brazil.

Marcelo Houat DE BRITO (D) https://orcid.org/0000-0001-7521-1388; Gabriela Almeida PIMENTEL (DD https://orcid.org/0000-0002-6576-850X; Marcos Fernando de Lima DOCEMA (D) https://orcid.org/0000-0002-7560-1463; Mateus Correa da TRINDADE (D) https://orcid.org/0000-0003-1572-8072 Correspondence: Marcelo Houat de Brito; E-mail:marcelohbrito@gmail.com Conflict of interest: There is no conflict of interest to declare.
}

Received on December 13, 2019; Received in its final form on March 08, 2020; Accepted on March 19, 2020. 